\title{
Contrasting seasonal patterns in dimethylsulfide, dimethylsulfoniopropionate, and chlorophyll $a$ in a shallow North Carolina estuary and the Sargasso Sea
}

\author{
William G. Sunda*, D. Ransom Hardison \\ National Ocean Service, NOAA, 101 Pivers Island Road, Beaufort, North Carolina 28516, USA
}

\begin{abstract}
Time series measurements of dimethylsulfide (DMS), particulate dimethylsulfoniopropionate $\left(\mathrm{DMSP}_{\mathrm{p}}\right)$, chlorophyll a (chl a), algal pigments, major nutrients, and the potential activity of DMSP lyase enzymes were made over a 2 yr period (6 March 2003 to 28 March 2005) near the mouth of the shallow, tidally mixed Newport River estuary, North Carolina, USA. DMSP ${ }_{p}$ had a mean of $43 \pm$ $20 \mathrm{nM}$ (range $=10.5$ to $141 \mathrm{nM}, \mathrm{n}=85$ ) and DMS a mean of $2.7 \pm 1.2 \mathrm{nM}$ (range $=0.9$ to $7.0 \mathrm{nM}$ ). The mean DMS in Gallants Channel was not significantly different from that measured in the Sargasso Sea near Bermuda during a previous 3 yr time series study $(2.4 \pm 1.5 \mathrm{nM})$, despite there being a 43 fold higher mean chl a concentration $\left(4.9 \pm 2.4 \mathrm{\mu g} \mathrm{l}^{-1}\right)$ at the coastal site. In winter, DMS was low and chl a was high in the surface waters of the Sargasso Sea, while the opposite was true at the coastal site. Consequently, DMS concentrations per unit algal chl a were on average 170 times higher in the Sargasso Sea than at the coastal site during the summer, but only 7 times higher during the winter. The much higher chl a-specific DMS concentrations at the oceanic site during the summer were linked to higher ratios of intracellular DMSP substrate and DMSP lyase enzyme per unit chl a. These differences in turn appear to be linked to large differences in nutrient concentrations and solar UV stress at the 2 sites and to associated differences in the composition of algal assemblages and physiological acclimation of algal cells.
\end{abstract}

KEY WORDS: Dimethylsulfide - DMS - Dimethylsulfoniopropionate - DMSP · DMSP lyase · Phytoplankton $\cdot$ Chlorophyll $a \cdot$ Pigments $\cdot$ Nutrients $\cdot$ Seasonal patterns $\cdot$ Climate

\section{INTRODUCTION}

The climatically active gas dimethylsulfide (DMS) is produced from the enzymatic cleavage of the algal metabolite dimethylsulfoniopropionate (DMSP). Some of the released DMS diffuses into the marine atmosphere where it is oxidized to acidic sulfur aerosols that nucleate clouds (Bates et al. 1987). These aerosols directly reflect sunlight and regulate cloud solar reflectance, thereby influencing the earth's heat balance (Charlson et al. 1987). A negative feedback regulation of the earth's climate has been proposed based on an observed positive seasonal relationship between solar radiation, surface ocean DMS, and DMS release to the atmosphere (Bates et al. 1987, Charlson et al. 1987, Vallina \& Simó 2007). However, the mechanisms responsible for this seasonal pattern are unclear (Dacey et al. 1998, Simó \& Pedros-Alio 1999). Recent studies suggest that this linkage may be caused by complex interactions among DMS production, cellular stress, nutrient limitation, and exposure to solar UV radiation (Sunda et al. 2002, 2007, Toole \& Siegel 2004). Understanding these interactions requires knowledge of the biological functions of DMSP and its cleavage products (DMS and acrylate) and the factors that regulate their production.

DMSP occurs at high intracellular concentrations (100 to $300 \mathrm{mmol} \mathrm{l}^{-1}$ ) and serves as an osmolyte in 
certain groups of marine algae, including prymnesiophytes, dinoflagellates, chrysophytes, and pelagophytes (Keller et al. 1989a,b). Other algal groups, including diatoms, cryptomonads, chlorophytes, and cyanobacteria typically produce little or no DMSP. Many DMSP-containing marine algae (and some bacteria) possess DMSP cleavage enzymes, which catalyze DMSP breakdown into DMS and acrylate or other compounds (Cantoni \& Anderson 1956, Steinke et al. 1998, Todd et al. 2007). DMSP and its breakdown products may serve other biological functions, although not equally in all algal species. DMSP, acrylate, DMS, and the oxidation product dimethylsulfoxide (DMSO) appear to serve as antioxidants by scavenging hydroxyl radicals and other reactive oxygen species (Sunda et al. 2002). This enables the cells to cope with a number of environmental stresses, including solar UV radiation, nutrient limitation, and variable light, which promote the production of reactive oxygen species. DMSP concentrations and enzymatic lysis to DMS within individual algal species are often up-regulated when these types of stresses occur (Keller et al. 1999, Sunda et al. 2002,2007 ). These same environmental factors can also influence concentrations of DMSP and the activity of DMSP lyase enzymes by selecting suites of algal species with different capacities to synthesize DMSP and DMSP lyase enzymes.

The enzymatic lysis of DMSP also may act as a grazing defense mechanism owing to the toxicity of released acrylate (Wolfe et al. 1997) or the ability of DMS or acrylate to serve as grazer deterrent signaling molecules (Lyons et al. 2007). Many DMSP lyase enzymes are largely inactive in non-stressed algal cells, likely due to their physical separation from DMSP substrate within cell compartments (Wolfe \& Steinke 1996). Physical disruption of cells during grazing allows the enzyme and substrate to combine, thereby releasing acrylate and DMS (Wolfe et al. 1997).

There have been numerous studies of the distributions of DMS and particulate (algal) DMSP in coastal and oceanic waters, but there have been relatively few seasonal time series studies. One of the most extensive of these is the 3 yr study of Dacey et al. (1998) at Hydrostation S in the Sargasso Sea. In that study, DMS was highest in the late spring and summer when chlorophyll a (chl a) was lowest, a pattern that appears to occur worldwide in the open ocean (Bates et al. 1987, Vallina \& Simó 2007). In seasonal studies in productive coastal waters, maximum DMS and DMSP concentrations often occurred during winter or spring in contrast to oceanic patterns (Kwint \& Kramer 1996, Moret et al. 2000, Jean et al. 2006).

We conducted a 2 yr time series study of DMS and particulate DMSP $\left(\mathrm{DMSP}_{\mathrm{p}}\right)$ in Gallants Channel, North Carolina, USA, near the mouth of the Newport River estuary. The estuary is a small $\left(27 \mathrm{~km}^{2}\right)$ shallow coastal system with an average depth of $\sim 1 \mathrm{~m}$ at mean low tide and a tidal excursion of $0.8 \mathrm{~m}$ (Litaker et al. 1987). The water depth at the Beaufort Laboratory dock collection site was 4 to $5 \mathrm{~m}$. In addition to DMS and DMSP, we also analyzed samples for chl $a$, salinity, temperature, diagnostic algal pigments, nutrients, and the potential activity of DMSP lyase enzymes. A major objective of the present study was to compare the seasonal patterns at this shallow, productive coastal site with those previously observed at the oligotrophic Hydrostation S near Bermuda (Dacey et al. 1998). The Gallants Channel and Bermuda sites have similar latitudes (34.7 and $32.2^{\circ} \mathrm{N}$, respectively) and thus have similar daily photoperiods at the same time of the year. However, surface waters at the 2 sites have considerably different concentrations of nutrients and chl $a$, exposure to solar UV radiation, water depths, and seasonal hydrographic patterns. Our goal was to compare the seasonal patterns at these contrasting sites to provide a better understanding of the processes and environmental factors that regulate DMSP and DMS concentrations at the sea's surface.

\section{MATERIALS AND METHODS}

Sampling. Samples were collected from the Beaufort Laboratory dock in Gallants Channel $\left(34.7^{\circ} \mathrm{N}, 76.7^{\circ} \mathrm{W}\right)$ in the lower Newport River estuary, North Carolina, USA, over a 2 yr period (6 March 2003 to 28 March 2005). Samples were collected at $\sim 10: 00 \mathrm{~h}$ at either slack high or low tides, depending on the tidal cycle. Samples were taken every $8 \mathrm{~d}$ on average and were measured for temperature, salinity, chl a, dissolved DMS, $\mathrm{DMSP}_{\mathrm{p}}$ and dissolved DMSP $\left(\mathrm{DMSP}_{\mathrm{d}}\right)$. Samples were also analyzed for algal pigments, major nutrients (ammonium, nitrate + nitrite, and phosphate), and the potential activity of DMSP lyase enzymes over most, but not all, of the 2 yr sampling period. Water samples were collected with a clean polypropylene bucket attached to a polypropylene rope. Water temperature was measured with a glass thermometer and salinity with a refractometer immediately after sample collection.

DMSP and DMS. Following collection, water samples were transferred to the laboratory within $5 \mathrm{~min}$ for analysis of DMS, DMSP , and DMSP ${ }_{d}$. DMS was measured using a modification of the purge and cryotrap method of Kiene \& Gerard (1994). To measure DMS, an $8 \mathrm{ml}$ subsample was gently filtered with a $10 \mathrm{ml}$ glass syringe through a $25 \mathrm{~mm}$ GF/F glass fiber filter using gravity only (from the sample and syringe plunger) to force the sample through the filter. Two $3 \mathrm{ml}$ portions of sample filtrate were placed in $14 \mathrm{ml}$ glass septum vials and the vials were promptly sealed. Two needles were 
inserted through the septum into each vial, the first used to bubble the sample with helium for $5 \mathrm{~min}$, and the second to transfer the gas from the vial to a Nafion dryer and cryotrap. The cryotrap was subsequently immersed in boiling water and the released DMS was measured with a Shimadzu GC 14-A gas chromatograph fitted with a flame photometric detector.

To measure $\mathrm{DMSP}_{\mathrm{p}}$ and $\mathrm{DMSP}_{\mathrm{d}}$, a $3 \mathrm{ml}$ subsample was placed in a $200 \mathrm{ml}$ filter tower and gently filtered through a $25 \mathrm{~mm}$ GF/F glass fiber filter into a $125 \mathrm{ml}$ suction flask. A hand pump (Nalgene Mityvac II) was used and just enough vacuum pressure was applied to permit slow passage of the sample through the filter. This method was required because gravity pressure alone was insufficient for sample filtration. $\mathrm{DMSP}_{d}$ and DMSP $_{p}$ were measured by base hydrolysis of DMSP to DMS and analysis of the released DMS by gas chromatography. To measure $\mathrm{DMSP}_{\mathrm{p}}$, each GF/F filter was placed in $3 \mathrm{ml}$ of $5 \mathrm{~N} \mathrm{NaOH}$ in a $14 \mathrm{ml}$ glass septum vial to hydrolyze DMSP to DMS. To measure DMSP ${ }_{\mathrm{d}}$ plus DMS, $3 \mathrm{ml}$ portions of sample filtrate were similarly placed in septum vials containing $3 \mathrm{ml}$ of $5 \mathrm{~N} \mathrm{NaOH}$. The vials were promptly sealed, incubated overnight, and then analyzed for released DMS (plus any originally present in the sample) by gas chromatography as described above. To quantify $\mathrm{DMSP}_{\mathrm{d}}$, the DMS measured after base hydrolysis was corrected for the DMS originally measured in the sample filtrate. Two sample replicates were analyzed for each parameter. The average range about the mean was $5.8 \%$ for DMS and $8.8 \%$ for $\mathrm{DMSP}_{\mathrm{p}}$.

Nutrient analyses. Subsamples of 40 to $50 \mathrm{ml}$ were syringe filtered $(0.2 \mu \mathrm{m}$, Supor $)$ into sterile $50 \mathrm{ml}$ polypropylene vials and were promptly frozen at $-20^{\circ} \mathrm{C}$ until analysis. Nutrient analysis was performed using an Alpkem Flow Solution IV gas segmented nutrient analyzer. Standard colorimetric procedures were followed for nitrate-nitrite, phosphate, and ammonium analyses (Parsons et al. 1984).

Phytoplankton pigments. All samples were measured for chl a using the standard fluorescence method, following extraction of GF/F filtered cells into a mixture of $90 \%$ acetone and $10 \%$ water (Parsons et al. 1984). In addition, 71 of the 85 samples were analyzed for algal pigments by HPLC analysis. For this analysis, 0.5 to $1.0 \mathrm{l}$ of sample water was filtered through a $47 \mathrm{~mm}$ GF/F filter using gentle vacuum ( $<10 \mathrm{~cm} \mathrm{Hg}$ ). Each filter was folded, blotted dry, frozen in liquid nitrogen, and stored at $-80^{\circ} \mathrm{C}$ until analysis. Algal pigments were extracted and quantified as previously described (Ornolfsdottir et al. 2003). An Agilent HP 1100 HPLC, fitted with a single monomeric $\mathrm{C}_{18}$ column (Agilent Hypersil ODS, $0.46 \times 10 \mathrm{~cm}, 5 \mu \mathrm{m}$ ) and 2 polymeric $\mathrm{C}_{18}$ columns (Vydac $201 \mathrm{TP}, 0.46 \times 25 \mathrm{~cm}, 5$ $\mu \mathrm{m})$ in series, was used to separate the extracted pig- ments. Absorption spectra and chromatograms (440 $\mathrm{nm})$ were acquired using an Agilent HP1100 photodiode array detector (model G1315B). Chl a values measured by HPLC were on average $93 \pm 13 \%( \pm \mathrm{SD})$ of those measured by fluorescence.

DMSP lyase potential activity. The potential activity of DMSP cleavage enzymes was determined by measuring the production rate of DMS at a near-saturating DMSP concentration ( $5 \mathrm{mM}$ ) in plankton cells lysed or permeabilized by chemical treatment, as described by Harada et al. (2004). The permeabilization is necessary because most DMSP cleavage enzymes are inactive in healthy, non-stressed algal cells, likely due to their physical separation from intracellular DMSP pools (Wolfe \& Steinke 1996). The measured DMS production rates thus represent DMS production potential and are hereafter referred to as DMSP lyase potential activity (DLPA). However, in addition to lyase enzymes, the method should also detect the potential activity of non-lyase cleavage enzymes such as those present in some bacteria (Todd et al. 2007).

For each assay, cells from $50 \mathrm{ml}$ of sample water were filtered onto a $25 \mathrm{~mm} \mathrm{GF/F} \mathrm{filter.} \mathrm{The} \mathrm{filter} \mathrm{was}$ placed in a $14 \mathrm{ml}$ septum vial and $1 \mathrm{ml}$ of $0.2 \mathrm{M}$ Tris buffer ( $\mathrm{pH}$ 8.0) containing $0.5 \mathrm{M} \mathrm{NaCl}$ was added to lyse or permeabilize the cells. The vial was sealed, vortexed, and incubated at $30^{\circ} \mathrm{C}$ for $20 \mathrm{~min}$. The assay was initiated by addition of DMSP at a concentration of $5 \mathrm{mM}$. Immediately prior to sampling, the vial was vortexed for $3 \mathrm{~s}$ to equilibrate the headspace with the liquid, and a $100 \mu$ l headspace sample was removed with a gas tight syringe and injected into a gas chromatograph for DMS measurement. Two replicate vials were prepared for each water sample. At least 3 headspace samples were measured for each vial over a 2 to $3 \mathrm{~h}$ period to yield a rate of DMS increase with time. The DMSP lysis rates in samples were corrected for abiotic cleavage of DMSP measured in control vials containing Tris buffer and no added filter. DLPA values are given in units of nmol of DMS released per minute per liter of sample.

Nutrient addition experiment. An experiment was conducted with Gallants Channel water to determine the effect of nutrient addition on algal DMSP and DMSP lysis to DMS. Water was collected at high tide the morning of 16 July 2004 and was dispensed into four 11 polycarbonate bottles, 2 of which were amended with added nutrients $\left(32 \mu \mathrm{M} \mathrm{NaNO} \mathrm{Nan}_{3}\right.$ and $\left.2 \mu \mathrm{M} \mathrm{Na}_{2} \mathrm{HPO}_{4}\right)$. The bottles were wrapped in neutral density screens, which reduced incident sunlight to $31 \%$ of ambient levels, and were placed in an outdoor circulating water bath set at the ambient water temperature at the time of sampling $\left(27^{\circ} \mathrm{C}\right)$. Subsamples were collected at 24 and $48 \mathrm{~h}$ and analyzed for DMS, $\mathrm{DMSP}_{\mathrm{p}}$, and chl a as described above. 
Statistics. Linear regression analyses were conducted with the Microsoft Excel statistics package.

\section{RESULTS AND DISCUSSION}

\section{Gallants Channel seasonal patterns}

Considerable variability was observed in the measured parameters over the 2 yr sampling period (Fig. 1). Temperatures achieved a low of $\sim 7^{\circ} \mathrm{C}$ in late January and were uniformly high $\left(28\right.$ to $\left.31^{\circ} \mathrm{C}\right)$ from mid-June through early September (Fig. 1E). Salinity showed no clear seasonal trend, with the exception of uniformly high values of 36 to 37 during June to July 2004, an unusually dry period (Fig. 1F). Salinities were generally higher in high tide samples $(33.4 \pm 2.8)$ than in low tide samples $(30.2 \pm 4.3)$, but the differences were small.

DMS concentrations ranged from 0.9 to $7.0 \mathrm{nM}$ with a mean of $2.7 \pm 1.2 \mathrm{nM}(\mathrm{n}=85)$. Concentrations showed a downward trend during most of 2003 and then exhibited a series of 4 peaks during 2004 and early 2005 (Fig. 1A). DMS was significantly correlated with substrate concentration $\left(\mathrm{DMSP}_{\mathrm{p}}\right)(\mathrm{r}=0.50, \mathrm{p}<0.001)$ and DLPA ( $\mathrm{r}=0.47, \mathrm{p}=0.002)$, but was not correlated with $\mathrm{DMSP}_{\mathrm{d}}$, chl $a$, salinity or temperature $(\mathrm{p}>0.05)$. These and other correlations were based on linear regressions of log-transformed values of DMS, $\mathrm{DMSP}_{\mathrm{p}}$, $\mathrm{DMSP}_{\mathrm{d}}, \mathrm{DLPA}$, and chl $a$, and untransformed values of temperature and salinity.

Total DMSP (DMSP plus $_{\text {DMSP }}$ ) ranged from 12 to $169 \mathrm{nM}$ and had a mean $(48 \pm 22 \mathrm{nM}) 18$ times that of DMS. An average of $90 \pm 6 \%$ of the total DMSP occurred as $\mathrm{DMSP}_{\mathrm{p}}$. However, the $10 \%$ on average measured as $\mathrm{DMSP}_{\mathrm{d}}$ may be an overestimate because of potential release of DMSP from algal cells during filtration, which can occur even under the most gentle filtration conditions (Kiene \& Slezak 2006). Because of such potential artifacts, we focus primarily on the $\mathrm{DMSP}_{\mathrm{p}}$ data (Fig. 1B). Since DMSP ${ }_{\mathrm{d}}$ accounted for only $10 \%$ on average of total DMSP, any cell leakage during filtration would have had only a minor effect on $\operatorname{DMSP}_{\mathrm{p}}$ data. $\mathrm{DMSP}_{\mathrm{p}}$ was negatively correlated with temperature $(\mathrm{r}=-0.28, \mathrm{p}<0.01)$, and was not significantly correlated with chl $a(\mathrm{p}=0.83)$ or salinity $(\mathrm{p}=$ $0.33)$.

Fig. 1. Two year time series for (A) DMS (dimethylsulfide) concentration, (B) particulate dimethylsulfoniopropionate $\left(\mathrm{DMSP}_{\mathrm{p}}\right),(\mathrm{C}) \mathrm{chl}$ a (fluorescence method), (D) DMSP lyase potential activity (DLPA), (E) temperature and (F) salinity at the Beaufort Dock sampling site in Gallants Channel. Data are plotted vs. number of days from January 2003. Vertical dashed lines separate the years 2003, 2004, and 2005
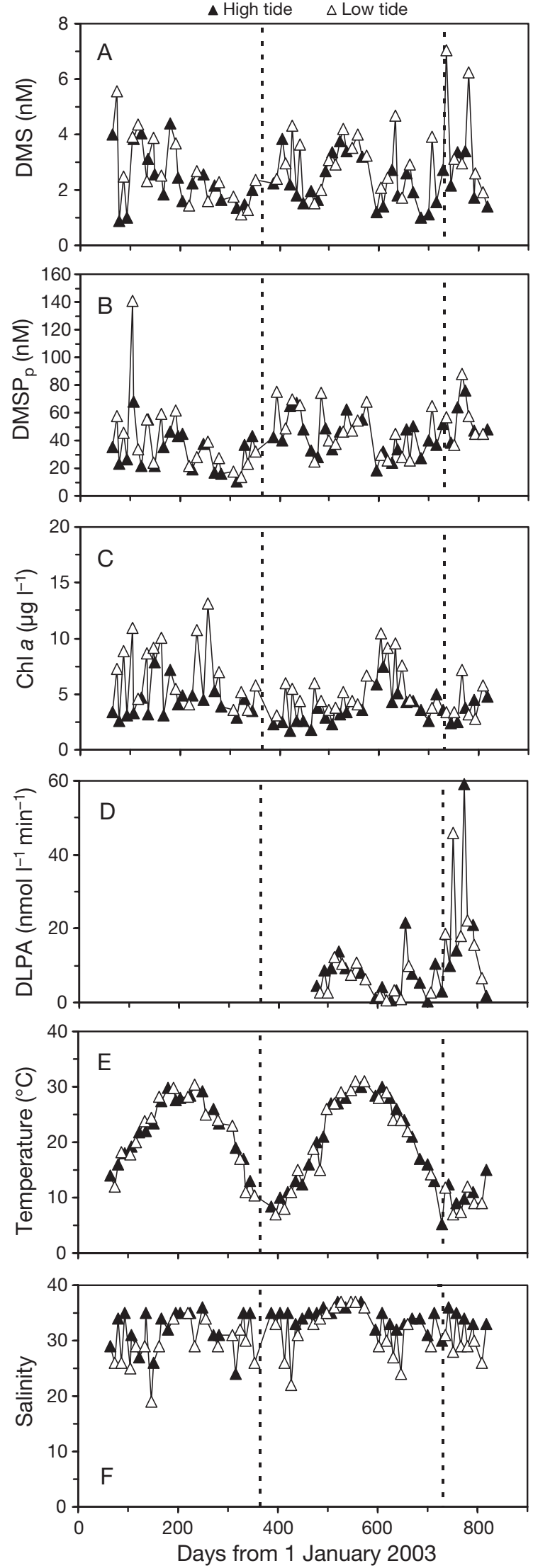
DLPA was measured only during the second year. Values ranged from 0.41 to $59 \mathrm{nmol} \mathrm{l}^{-1} \mathrm{~min}^{-1}$ and had a mean of $10.4 \pm 11.6 \mathrm{nmol} \mathrm{l}^{-1} \mathrm{~min}^{-1}$. There were 3 separate peaks in DLPA (Fig. 1D), which roughly coincided with the peaks for DMS (Fig. 1A). DLPA was significantly correlated with DMS (see above) and $\mathrm{DMSP}_{\mathrm{p}}$ $(r=0.50, p=0.001)$, but was not correlated with $\operatorname{DMSP}_{d}$ $(\mathrm{p}=0.82)$.

Chl a concentrations ranged from 1.8 to $13.1 \mu \mathrm{g} \mathrm{l}^{-1}$, with a mean of $4.9 \pm 2.4 \mathrm{ug} \mathrm{l}^{-1}$ (Fig. 1C). Chl $a$ was negatively correlated with salinity $(\mathrm{r}=-0.48, \mathrm{p}<0.001)$, likely resulting from stimulation of algal growth with freshwater inputs of nutrients. This linkage is supported by a negative correlation between inorganic nitrogen concentration (ammonium + nitrate + nitrite) and salinity $(\mathrm{r}=-0.62, \mathrm{p}<0.001, \mathrm{n}=36)$.

Although there were considerable variations in DMS and $\mathrm{DMSP}_{\mathrm{p}}$ during any given season, significant seasonal trends were observed. Based on linear regressions of log-transformed data vs. day of the year, $\mathrm{DMSP}_{\mathrm{p}}$ and DMS were highest on average during the winter and showed significant downward trends from spring to early fall (Table 1). Mean DMS and DMSP $p$ concentrations were $1.3 \pm 0.3$ and $24 \pm 12 \mathrm{nM}$, respectively, in November $(\mathrm{n}=6)$ and increased to $3.5 \pm 1.3$ and $59 \pm 15 \mathrm{nM}$, respectively, in February and early March $(\mathrm{n}=12)$. Regression analysis of total DMSP yielded the same slope and correlation coefficient as that for $\mathrm{DMSP}_{\mathrm{p}}$ (Table 1), reflecting the high percentage of DMSP in particles (see above). By contrast, $\mathrm{DMSP}_{\mathrm{d}}$ data were variable and showed no significant seasonal trend (Table 1).

DLPA showed a similar seasonal trend to $\mathrm{DMSP}_{\mathrm{p}}$ and DMS, although the timing was slightly different (Table 1). The highest values were observed in winter, and there was a significant downward trend from midwinter through late summer.

Table 1. Results of linear regressions of the natural log of various measured parameters (e.g. ln DMS [dimethylsulfide]) vs. day of the year (Day $1=1 \mathrm{Jan}$ ). $\mathrm{DMSP}_{\mathrm{p}}$ and $\mathrm{DMSP}_{\mathrm{d}}$ : particulate and dissolved dimethylsulfoniopropionate, respectively; DLPA: DMSP lyase potential activity. DMS and DMSP showed slightly different seasonal patterns from DLPA and chl $a$. Thus, regressions were made over different time periods

\begin{tabular}{|lccccc|}
\hline Parameter & Days of year & $\mathrm{r}$ & Slope $\left(\mathrm{d}^{-1}\right)$ & $\mathrm{p}$ & $\mathrm{n}$ \\
\hline DMS & $40-335$ & -0.36 & -0.0018 & 0.002 & 72 \\
Total DMSP & $40-335$ & -0.50 & -0.0027 & $<0.001$ & 72 \\
DMSP $_{\mathrm{p}}$ & $40-335$ & -0.50 & -0.0027 & $<0.001$ & 72 \\
DMSP $_{\mathrm{d}}$ & $40-335$ & -0.22 & -0.0016 & 0.06 & 70 \\
DLPA & $5-272$ & -0.71 & -0.0092 & $<0.001$ & 31 \\
Chl a & $5-272$ & 0.48 & 0.0030 & $<0.001$ & 67 \\
DMS:chl a & $5-272$ & -0.49 & -0.0040 & $<0.001$ & 67 \\
DMSP $: \operatorname{chl} a$ & $5-272$ & -0.63 & -0.0054 & $<0.001$ & 67 \\
DLPA:chl $a$ & $5-272$ & -0.74 & -0.0119 & $<0.001$ & 31 \\
\hline
\end{tabular}

Table 2. DMS:chl a and DMSP :chl a molar ratios and carotenoid abundance (as mol \% of the carotenoid pool) in Gallants Channel during winter $(\mathrm{n}=18)$ and summer $(\mathrm{n}=12)$. Chl a was determined by HPLC

\begin{tabular}{|c|c|c|}
\hline & Summer & Winter \\
\hline DMS:chl a & $0.46 \pm 0.24$ & $1.05 \pm 0.73$ \\
\hline $\operatorname{DMSP}_{\mathrm{p}}: \operatorname{chl} a$ & $7.1 \pm 3.9$ & $17.9 \pm 13.2$ \\
\hline Fucoxanthin & $59.3 \pm 13.3$ & $50.1 \pm 15.0$ \\
\hline Zeaxanthin & $13.7 \pm 6.1$ & $1.7 \pm 1.7$ \\
\hline Diadinoxanthin & $9.8 \pm 3.0$ & $16.6 \pm 4.3$ \\
\hline$\beta$-carotene & $9.9 \pm 3.9$ & $5.7 \pm 2.8$ \\
\hline Alloxanthin & $2.5 \pm 2.9$ & $5.2 \pm 3.1$ \\
\hline Peridinin $^{\mathrm{a}}$ & $1.7 \pm 3.3$ & $12.8 \pm 9.8$ \\
\hline $19^{\prime}-$ hex $^{\mathrm{a}}$ & $0.7 \pm 1.1$ & $2.1 \pm 2.4$ \\
\hline Violaxanthin & $0.9 \pm 1.5$ & $2.8 \pm 2.1$ \\
\hline \multicolumn{3}{|c|}{$\begin{array}{l}\text { adiagnostic pigments for high-DMSP and high-DLPA } \\
\text { algal groups: peridinin in dinoflagellates and } 19^{\prime} \text {-hexa- } \\
\text { noyloxyfucoxanthinin }\left(19^{\prime} \text {-hex) in prymnesiophytes }\right.\end{array}$} \\
\hline
\end{tabular}

Chl a showed an opposite seasonal pattern to DLPA, and was lowest during the late fall and early winter and increased significantly between January and September (Table 2, Fig. 2A). The mean chl a concentration was $3.2 \pm 0.6 \mu \mathrm{g} \mathrm{l}^{-1}(\mathrm{n}=6)$ in January and $7.8 \pm$ $3.0 \mathrm{\mu g} \mathrm{l}^{-1}(\mathrm{n}=11)$ in late August and September. Because of the opposing seasonal trends between chl a and the other parameters, ratios of $\mathrm{DMSP}_{\mathrm{p}}$ DMS, and DLPA to chl a decreased even more on a relative basis from January through September than did $\operatorname{DMSP}_{\mathrm{p}}$, DMS, and DLPA (Table 1, Fig. 2B-D).

\section{Algal pigments}

Pigment data suggest that seasonal trends in $\mathrm{DMSP}_{\mathrm{p}}$ and DMS were at least partly linked to variations in algal community composition (Fig. 3). Diatoms appeared to be the dominant algal group - as has previously been reported for Gallants Channel (Tester et al. 1995) - based on the abundance of the diatom pigment fucoxanthin (Jeffrey \& Vesk 1997), which comprised $59 \mathrm{~mol} \%$ of the carotenoid pool in summer and $50 \mathrm{~mol} \%$ in winter (Table 2). Zeaxanthin, a biomarker pigment for cyanobacteria (Jeffrey \& Vesk 1997), was much more abundant during summer than in winter (13.7 vs. $1.7 \mathrm{~mol} \%$ of the carotenoids) while alloxanthin, a biomarker for cryptophytes, was somewhat lower in summer (2.5 vs. $5.2 \mathrm{~mol} \%$ ) (Table 2, Fig. 3B). Diatoms and cryptophytes 


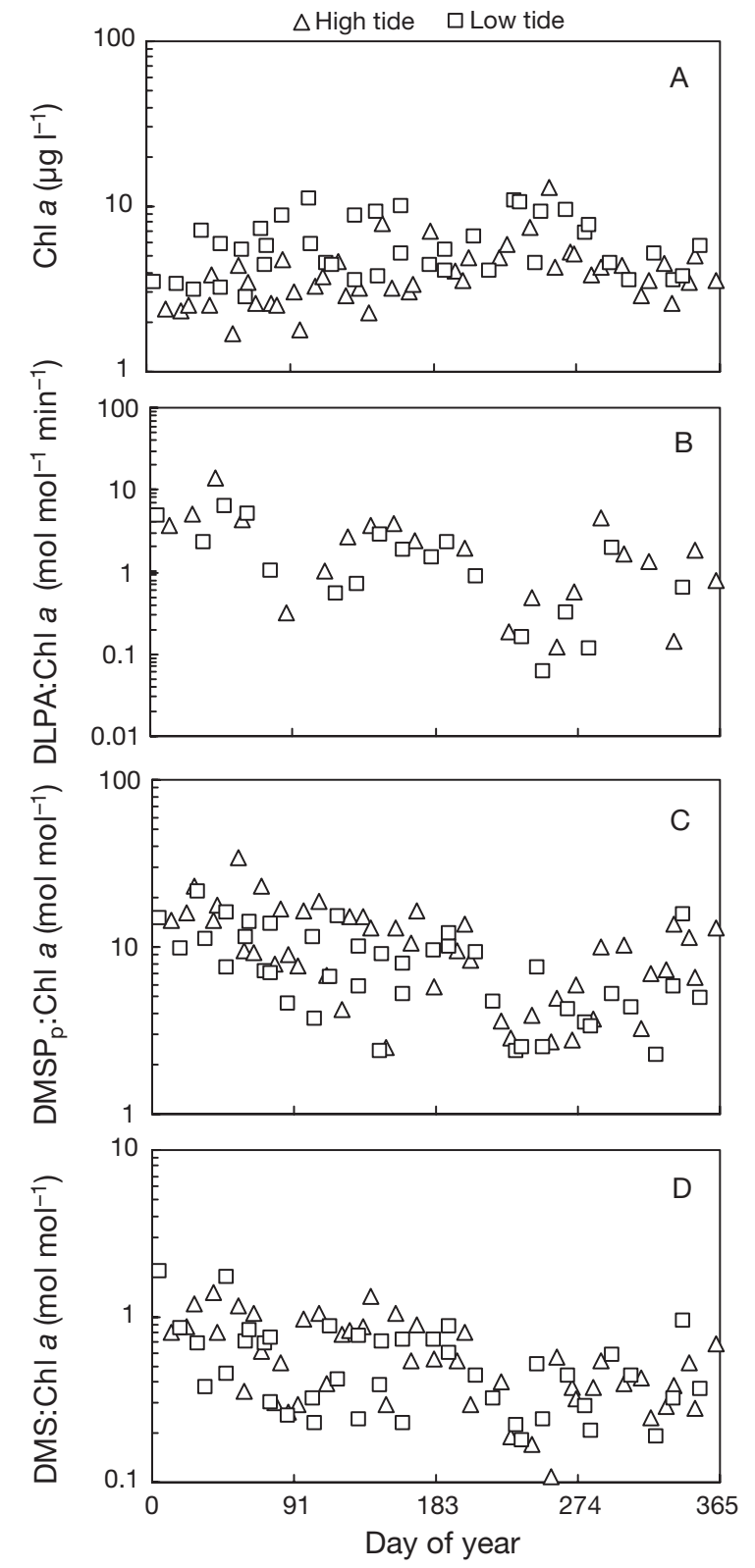

Fig. 2. (A) Chl $a$ and ratios of (B) DLPA:chl $a_{1}(\mathrm{C}) \mathrm{DMSP}_{\mathrm{p}}$ :chl $a_{\text {, }}$ and (D) DMS:chl $a$ in Gallants Channel plotted vs. day of the year (Day $1=1 \mathrm{Jan}$ ). Chl $a$ and DMSP $_{\mathrm{p}}$ were measured over the entire 2 yr sampling period, while DLPA and DLPA:chl a were determined only during the last year (see Fig. 1). Chl a values were measured by fluorescence (see 'Materials and methods')

contain low DMSP levels and cyanobacteria are not known to synthesize DMSP (Keller et al. 1989a). Thus, our pigment data indicate a dominance by low-DMSP algal groups, especially during summer when DMSP $_{p}$ and DMS per unit of chl a were lowest (Table 2). There was an overall low occurrence of diagnostic pigments (peridinin and 19'-hexanoyloxyfucoxanthin [19'-hex]) for high-DMSP algal groups (dinoflagellates and

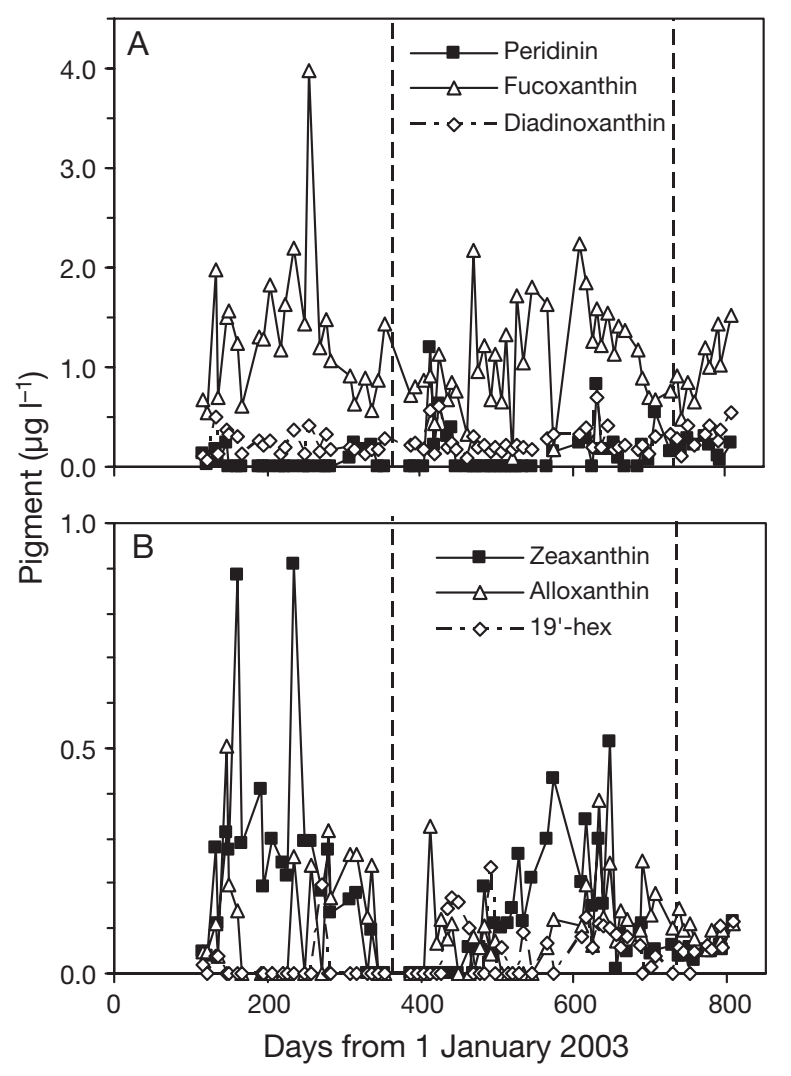

Fig. 3. Concentrations of biomarker algal pigments in Gallants Channel plotted vs. elapsed days from 1 January 2003. Vertical dashed lines separate the years 2003, 2004, and 2005

prymnesiophytes). Peridinin, which occurs in dinoflagellates, accounted for a 7 -fold higher mean percentage of the carotenoid pool in winter than in summer, while 19'-hex, which occurs in prymnesiophytes and in some dinoflagellates (e.g. Heterocapsa triquetra, Yoon et al. 2002), was 3-fold higher in winter. The higher winter abundance of the 2 pigments coincides with the higher winter ratios of DMSP $_{\mathrm{p}}$ and DMS to chl a (Table 2 ), and is consistent with the well documented winter blooms of dinoflagellates in the main body of the Newport River estuary (Litaker et al. 2002).

DMSP $_{\mathrm{p}}$ and DMS were not correlated to chl $a$ or most carotenoid pigments $(p>0.05)$. However, DMSP $_{p}$ was weakly correlated with the dinoflagellate pigment peridinin $(\mathrm{r}=0.26, \mathrm{p}=0.03)$ and with violaxanthin $(\mathrm{r}=$ $0.26, p=0.03)$, while DMS was weakly correlated with peridinin $(\mathrm{r}=0.28, \mathrm{p}=0.02)$ and diadinoxanthin $(\mathrm{r}=$ $0.26, p=0.03)$. The correlations with diadinoxanthin and violoxanthin may be linked to the function of these pigments in photoprotection within the photosynthetic apparatus (Porra et al. 1997) and the hypothesized function of DMSP and DMS in oxidative stress protection (Sunda et al. 2002). A similar correlation between 
diadinoxanthin and $\mathrm{DMSP}_{\mathrm{p}}$ has been observed in a tropical lagoon in Belize (Sunda et al. 2005). Diadinoxanthin in Gallants Channel was also significantly correlated with peridinin $(\mathrm{r}=0.62, \mathrm{p}<0.001)$, again as observed in the Belize lagoon (Sunda et al. 2005). These correlations appear to reflect the very high diadinoxanthin:chl a ratios in dinoflagellates, which are 3 times higher than in diatoms (Sunda et al. 2005). Thus, a much higher occurrence of dinoflagellates may explain the higher abundance of diadinoxanthin and DMSP $_{\mathrm{p}}$ in Gallants Channel during winter (Table 2).

\section{Comparison with other productive coastal sites}

Winter maxima in DMS have been observed at other productive coastal sites. In the shallow Venice Lagoon (1.2 m mean depth), DMS was highest in February, while in Little Bay, a eutrophic estuary near Toulon, France, DMSP and DMS maxima were observed in March, in conjunction with a bloom of dinoflagellates (Jean et al. 2006). Both of these Mediterranean sites are more northerly ( 43 to $45^{\circ} \mathrm{N}$ ) than Gallants Channel $\left(34.5^{\circ} \mathrm{N}\right)$, which may explain the slightly later seasonal peaks in DMS and DMSP. At a coastal site even farther north, Marsdiep Inlet, the Netherlands $\left(53^{\circ} \mathrm{N}\right)$, maximum DMS concentrations occurred even later, in April (Kwint \& Kramer 1996). Here, the DMSP and DMS maxima coincided with a bloom of Phaeocystis sp., a prymnesiophyte genus with high intracellular DMSP and high activities of DMSP lyase enzymes (Keller et al. 1989a, Stefels et al. 1995).

\section{Coastal-oceanic comparisons}

The higher DMS concentrations during winter or spring at many shallow productive coastal sites contrasts with the situation in oligotrophic ocean waters (Dacey et al. 1998, Vallina \& Simó 2007) and some oligotrophic shelf waters receiving minimal river nutrient input (Vila-Costa et al. 2008). To further examine these differences, we compared seasonal patterns in Gallants Channel with those previously reported at Hydrostation S in the Sargasso Sea (Dacey et al. 1998) (Figs. 4 to 7 ).

A striking feature of this comparison was the opposing seasonal patterns in DMS and chl a. In Sargasso surface waters, the mean DMS concentration was 3.6fold higher and mean chl a was 4.1-fold lower in the summer than in winter, which together resulted in a 13-fold higher mean summer DMS:chl a ratio (Fig. 4). This was opposite of the pattern in Gallants Channel, where the mean DMS:chl a ratio was 2.3-fold higher in winter than in summer (Table 2). Because of these
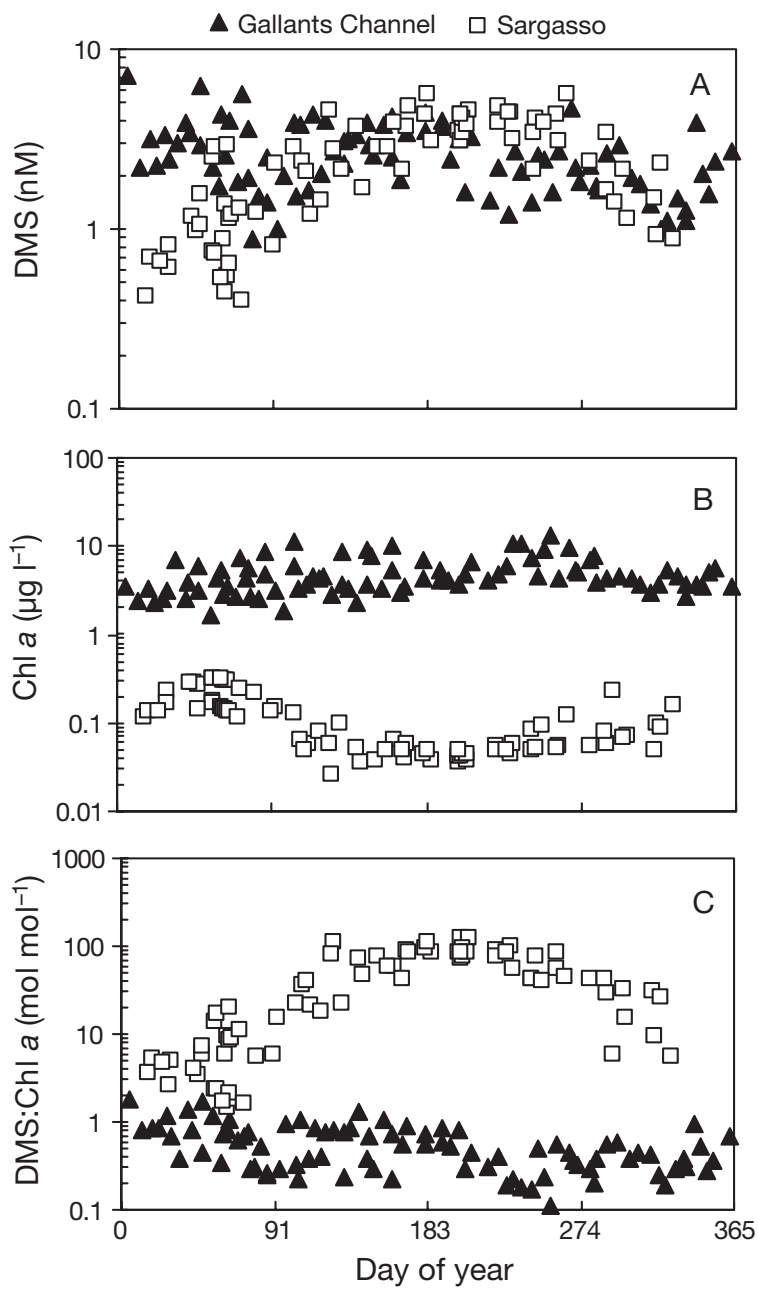

Fig. 4. (A) DMS, (B) chl a (fluorescence method), and (C) molar ratio of DMS:chl $a$ in Gallants Channel (6 March 2003 to 28 March 2005, n = 85) and Hydrostation S in the Sargasso Sea (29 January 1992 to 17 October 1994, n = 76; data from Dacey et al. 1998) plotted against day of the year

opposing patterns, differences in DMS:chl a ratios between the 2 sites varied substantially on a seasonal basis (Fig. 4C). During summer, these ratios were on average 170-fold higher in the Sargasso than in Gallants Channel, while in the winter the average ratio in the Sargasso was only 7 -fold higher. However, most of this large winter-summer difference is due to the seasonal differences in the Sargasso.

A second striking feature of the coastal-oceanic comparison is the similarity in DMS concentrations at the 2 sites during spring, summer, and fall despite 100fold lower chl a levels in the Sargasso (Fig. 4A,B). During this time, the much lower chl a biomass in the Sargasso is countered by higher DMS:chl a ratios, resulting in similar surface DMS concentrations.

A third striking feature was the greater DMS:DMSP ${ }_{p}$ ratios in the Sargasso than in Gallants Channel, indi- 

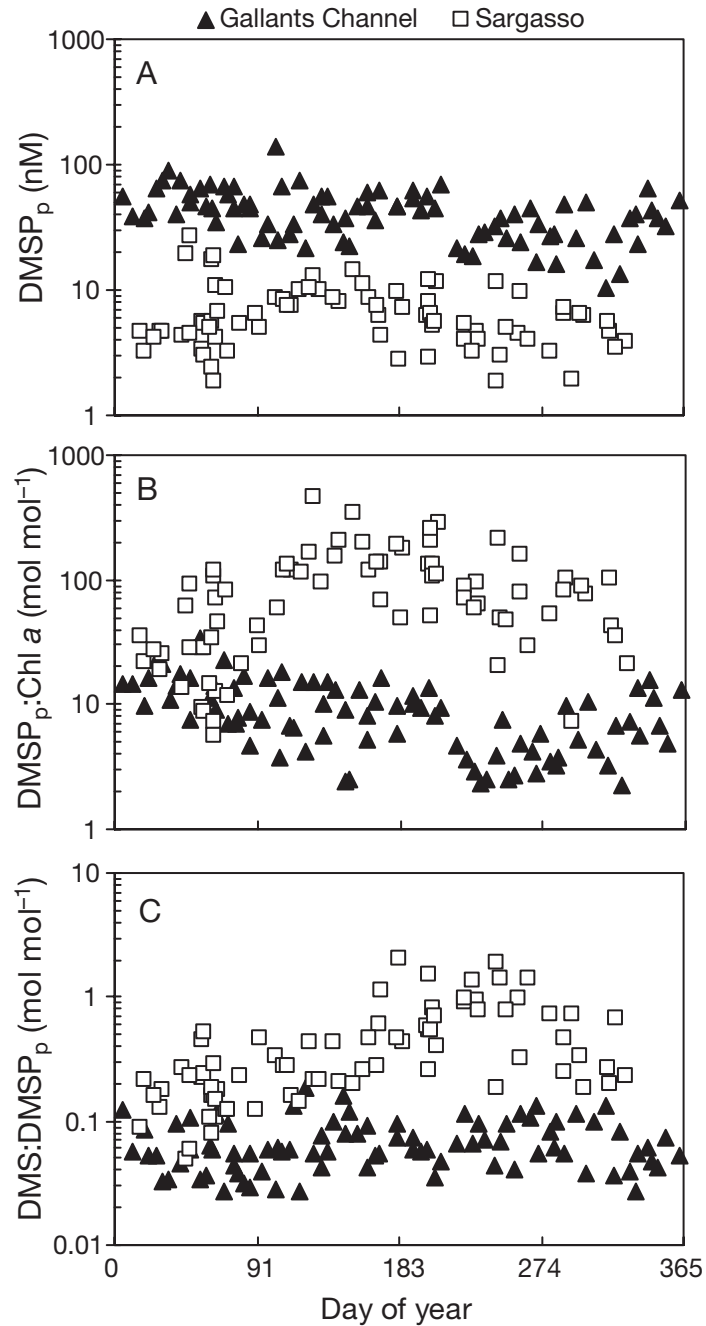

Fig. 5. (A) $\mathrm{DMSP}_{\mathrm{p}}$, (B) $\mathrm{DMSP}_{\mathrm{p}}$ :chl a molar ratio, and (C) DMS: DMSP $_{p}$ molar ratio in Gallants Channel and the Sargasso Sea (Dacey et al. 1998) plotted against day of the year. Chl a was measured by fluorescence

cating a higher net percent conversion of DMSP to DMS. The Sargasso ratios were 12-fold higher on average in the summer than those in Gallants Channel, but only 3-fold higher in winter, due almost entirely to seasonal variations in the Sargasso (Fig. 5C). DMS concentrations result from a net balance between rates of production from DMSP cleavage reactions and rates of loss via atmospheric out-gassing, photolysis, and microbial degradation (Toole \& Siegel 2004). A modeling analysis of the Sargasso time series data indicates that seasonal differences in DMS concentrations are due mainly to higher biological production rates of DMS during summer, and not to lower rates of DMS loss processes (Toole \& Siegel 2004).

Since DMS is derived from enzymatic cleavage of DMSP, it is useful to examine coastal-oceanic patterns in $\mathrm{DMSP}_{\mathrm{p}}$ and DLPA. The highest $\mathrm{DMSP}_{\mathrm{p}}$ levels in the
Sargasso generally occurred in April and May

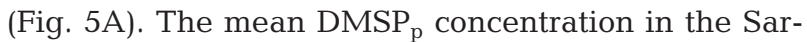
gasso was $14 \%$ of that in Gallants Channel and the differences were similar during winter and summer (Fig. 5A). DMSP:chl a ratios in the Sargasso were on average 20 -fold higher than those in Gallants Chan-
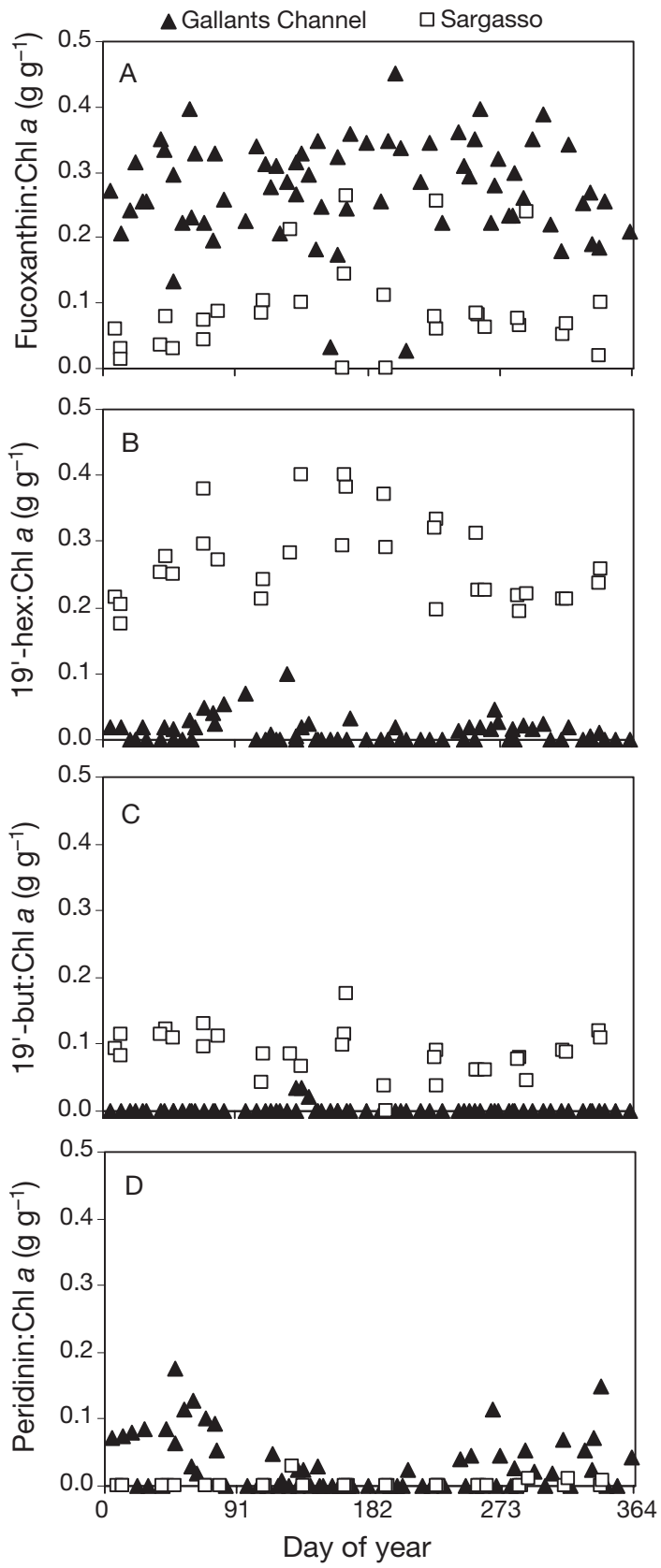

Fig. 6. Weight to weight ratios of (A) fucoxanthin:chl $a_{1}$ (B) 19'-hexanoyloxyfucoxanthin (19'-hex):chl $a_{1}$ (C) 19'-butanoyloxyfucoxanthin (19'-but):chl $a$, and (D) peridinin:chl $a$ in Gallants Channel (April 2003 to March 2005, n = 70) and the BATS time series station in the Sargasso Sea (February 1992 to December 1994, $\mathrm{n}=31$; data taken from http://bats.bios. edu) plotted against day of the year. All pigment data including chl a were measured by HPLC 


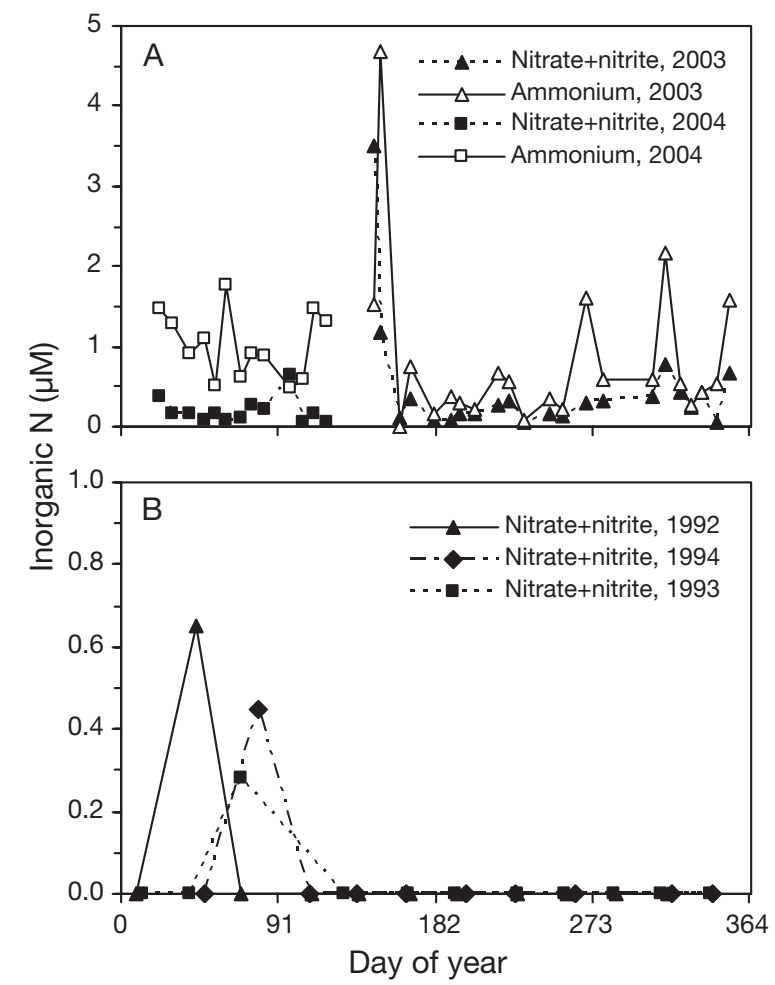

Fig. 7. Inorganic nitrogen (ammonium and nitrate + nitrite) at (A) the Beaufort Dock station in Gallants Channel and (B) the BATS time series station in the Sargasso Sea (data taken from http://bats.bios.edu). Data are plotted against day of the year

nel from mid-spring through summer, but ratios overlapped at the 2 sites during winter (Fig. 5B). Thus, at least part of reason for the 170-fold higher average DMS:chl a ratio in the Sargasso than in Gallants Channel during summer was the much higher chl-normalized levels of DMSP substrate in the Sargasso.

DLPA was not measured during the Sargasso time series study. However, data for DLPA, DMSP , and DMS have been reported for 5 low-chl a surface samples collected from the Sargasso (31 to $33^{\circ} \mathrm{N}, 69$ to

Table 3. DLPA $\left(30^{\circ} \mathrm{C}\right)$ and associated parameters in surface water from Gallants Channel (mid-March to mid-May 2004 and 2005, n =6) and the Sargasso Sea (April 2002, n =5, Harada et al. 2004). Values are means \pm SD

\begin{tabular}{|lccc|}
\hline & $\begin{array}{c}\text { Gallants } \\
\text { Channel }\end{array}$ & $\begin{array}{c}\text { Sargasso } \\
\text { Sea }\end{array}$ & $\begin{array}{c}\text { Relative } \\
\text { difference }\end{array}$ \\
\hline Temperature $\left({ }^{\circ} \mathrm{C}\right)$ & $18 \pm 6$ & $20 \pm 1$ & \\
Chl $a\left(\mu \mathrm{g} \mathrm{l}^{-1}\right)$ & $4.2 \pm 1.0$ & $0.073 \pm 0.043$ & 0.017 \\
DLPA $\left(\mathrm{nmol} \mathrm{l}^{-1} \mathrm{~min}^{-1}\right)$ & $4.5 \pm 2.7$ & $3.2 \pm 1.1$ & 0.71 \\
DLPA:chl $a\left(\mathrm{~mol} \mathrm{~min}^{-1} \mathrm{~mol}^{-1}\right)$ & $1.0 \pm 0.8$ & $50 \pm 10$ & 50 \\
DMSP $(\mathrm{nM})$ & $46 \pm 15$ & $18 \pm 7$ & 0.38 \\
DMSP $: \mathrm{chl} a\left(\mathrm{~mol} \mathrm{~mol}^{-1}\right)$ & $11.4 \pm 4.0$ & $183 \pm 20$ & 16 \\
DMS $(\mathrm{nM})$ & $2.1 \pm 0.6$ & $2.4 \pm 0.7$ & 1.1 \\
DMS:chl $a\left(\mathrm{~mol} \mathrm{~mol}^{-1}\right)$ & $0.49 \pm 0.24$ & $36 \pm 23$ & 72 \\
DMS:DMSP $\left(\mathrm{mol} \mathrm{mol}^{-1}\right)$ & $0.048 \pm 0.019$ & $0.20 \pm 0.13$ & 4.1 \\
\hline
\end{tabular}

$74^{\circ} \mathrm{W}$ ) during April 2002 near Hydrostation S (Harada et al. 2004). Mean $\mathrm{DMSP}_{\mathrm{p}}, \mathrm{DMS}$, and chl a values in these samples were similar to those measured at Hydrostation S during April (Table 3, Figs. 4 \& 5). Mean DLPA in the Sargasso samples was similar to that in Gallants Channel at the same time of year (Table 3). However, mean chl a in the Sargasso samples was only $1.7 \%$ of that in Gallants Channel, and consequently, mean DLPA normalized to chl a was 50fold higher in the Sargasso samples. Similarly large differences in DLPA: chl a ratios were observed between the surface Sargasso samples and those from productive high-chl sites in the Gulf of Maine (Harada et al. 2004). These large differences in DLPA per unit of chl a are thus a second major factor contributing to the much higher DMS:chl a ratios in the Sargasso compared to those at productive coastal sites. It also may explain the higher DMS:DMSP ${ }_{p}$ ratios in the Sargasso samples (Table 3, Fig. 5C).

The large differences in DMS, DMSP ${ }_{\mathrm{p}}$, and DLPA per unit of chl a are not linked to temperature since the largest differences occur from April to September when temperatures in the Sargasso and Gallants Channel were similar $\left(25.2 \pm 2.7\right.$ and $25.6 \pm 3.9^{\circ} \mathrm{C}$, respectively). Likewise, differences in solar irradiance cannot be the cause because the 2 sites have similar latitudes and thus similar seasonal day lengths. Variation in salinity is also an unlikely cause; the average salinity in Gallants Channel (31.9 \pm 3.9$)$ was only $13 \%$ less than that in the Sargasso $(36.6 \pm 0.1)$, and salinity had no significant effect on chl-normalized DMS, DMSP, or DLPA in Gallants Channel.

One factor that likely contributed to the higher values per unit of chl a in the Sargasso was the high abundance of prymnesiophytes and pelagophytes, as indicated by the high ratio of the prymnesiophyte biomarker pigment $19^{\prime}$-hex to chl a $\left(0.27 \pm 0.07 \mathrm{~g} \mathrm{~g}^{-1}\right)$ and the pelagophyte pigment 19'-but (19'-butanoyloxyfucoxanthin) to chl a $\left(0.09 \pm 0.03 \mathrm{~g} \mathrm{~g}^{-1}\right)$ (Fig. 6B,C) (Goericke 1998). By contrast, these pigments had very low ratios to chl a in Gallants Channel (0.01 \pm 0.02 and $0.001 \pm 0.006 \mathrm{~g} \mathrm{~g}^{-1}$, respectively), and there, as noted above, diatoms appeared to dominate the algal community based on the high abundance of fucoxanthin (Fig. 6A-C). Fucoxanthin also occurred in the Sargasso samples (Fig. 6A), but its presence is likely explained by its co-occurrence with 19'-hex in prymnesiophytes (Jeffrey \& Vesk 1997). Prymnesiophytes and pelagophytes typically contain high DMSP levels (Keller et al. 1989a,b), and some prymnesiophytes, 

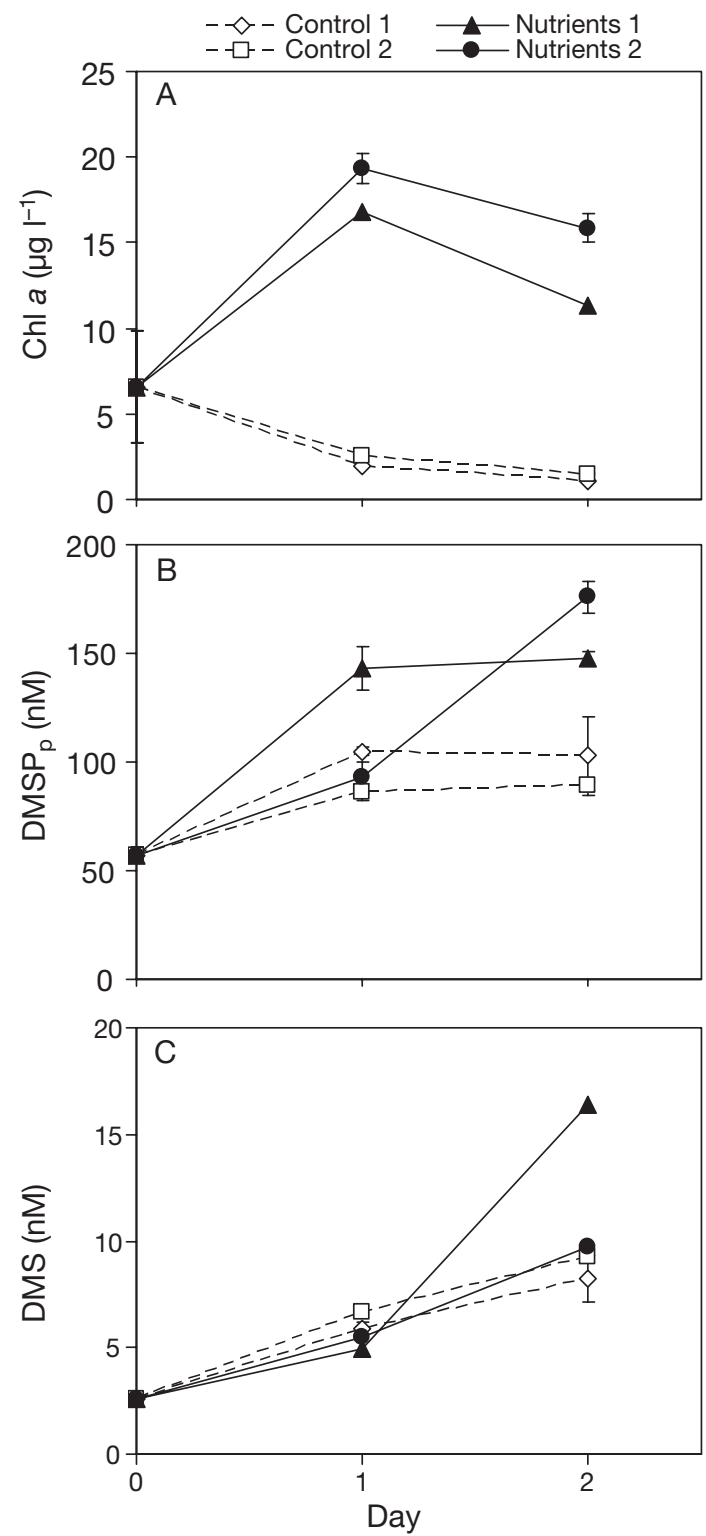

Fig. 8. Time-dependent changes in (A) chl $a_{1}$ (B) $\mathrm{DMSP}_{\mathrm{p}}$, and (C) DMS during the nutrient addition experiment with Beaufort Dock water (Gallants Channel) in July 2004. Added nutrients were $32 \mu \mathrm{mol} \mathrm{l} \mathrm{l}^{-1}$ nitrate and $2 \mu \mathrm{mol} \mathrm{l} \mathrm{l}^{-1}$ phosphate. Each treatment had 2 replicate bottles. Data plotted give mean \pm range for duplicate measurements in each bottle

such as Emiliania huxleyi (clone CCMP 373, isolated from the Sargasso), also have very high DLPA:chl ratios (Steinke et al. 1998). The average molar ratios of DMSP $_{\mathrm{p}}$ :chl $a$ in surface Sargasso waters $(38 \pm 33 \mathrm{~mol}$ $\mathrm{mol}^{-1}$ in winter and $120 \pm 73$ in summer) are close to those observed in light saturated E. huxlei (CCMP 374) grown under nutrient sufficiency and N-limitation $(75 \pm 25$ and $126 \pm 15$, respectively; Sunda et al. 2007). The dominance of diatoms in Gallants Channel can readily explain the much lower $\mathrm{DMSP}_{\mathrm{p}}$, DLPA, and
DMS normalized to chl $a$ in the coastal samples. The average $\mathrm{DMSP}_{\mathrm{p}}$ :chl a molar ratio $(7.1 \pm 3.9)$ in the coastal samples during summer when diatoms appear most abundant is close to the range (5 to 9) in Skeletonema costatum grown at saturating light and nutrients (Sunda et al. 2007). Skeletonema is a dominant diatom genus in Gallants Channel and other nutrientrich coastal waters (Tester et al. 1995).

Previous studies along the east coast of North America have reported similar large increases in DMS, DMSP $_{\mathrm{p}}$ and DLPA to chl ratios between highly productive coastal waters and adjacent oligotrophic oceanic waters, including studies in the Chesapeake Bay, Delaware Bay, and Sargasso Sea in September (Iverson et al. 1989), the Mississippi River Plume and oligotrophic waters of the Gulf of Mexico in September (Kiene \& Linn 2000), and the Gulf of Maine and the Sargasso Sea in April (Harada et al. 2004). As in the present study, the large differences in these ratios were attributed at least partly to the prevalence of diatoms in coastal waters and prymnesiophytes in oceanic waters, based on cell count data (Iverson et al. 1989) or algal pigment analysis (Harada et al. 2004).

\section{Nutrient effects}

Although coastal-oceanic differences in DMSP, DLPA, and DMS normalized to chl a appear to be related at least in part to differences in species composition, this begs the question of the underlying causes of these species differences. Diatoms are classic highnutrient $(r$-selected) species and dominate algal communities under high nutrient conditions, while prymnesiophytes in oligotrophic ocean waters are usually low-nutrient ( $K$-selected) species (Kilham \& Kilham 1980, Sunda \& Hardison 2007). Thus, one potential underlying cause of the large differences in species composition is a difference in nutrient concentrations.

To investigate this possibility, we compared inorganic nitrogen and phosphorus levels in Gallants Channel and the Sargasso. Ammonium $\left(\mathrm{NH}_{4}{ }^{+}\right)$and nitrate plus nitrite $\left(\mathrm{NO}_{\mathrm{x}}^{-}\right)$concentrations were $0.90 \pm$ $0.85 \mu \mathrm{M}$ and $0.36 \pm 0.60 \mu \mathrm{M}$, respectively, in Gallants Channel and showed no clear seasonal trends (Fig. 7A). In only 2 of 35 samples did $\mathrm{NH}_{4}{ }^{+}$fall below $0.1 \mu \mathrm{M}$, the minimum level needed to support maximum growth rate of diatoms (Sunda et al. 2007). The mean phosphate concentration was $0.19 \pm 0.12 \mu \mathrm{M}$ ( $\mathrm{n}=$ 37 , data not shown), and given the molar N:P ratio of $\sim 16$ needed to support maximum growth rate of diatoms (Goldman et al. 1979), phosphate is also unlikely to have been limiting. Thus, the presence of nutrient-sufficient growth conditions for diatoms in Gallants Channel can readily explain the dominance of 
this $r$-selected algal group. The predominance of ammonium over nitrate is consistent with a largely regenerated nitrogen supply (Litaker et al. 1987).

By contrast, inorganic $\mathrm{N}$ concentrations in surface Sargasso waters were extremely low and fall within the range that limits algal growth rate. During the Sargasso time series study, $\mathrm{NO}_{\mathrm{x}}^{-}$levels were below the detection limit $(0.05 \mu \mathrm{M})$, except briefly during February or March when cold temperatures and winter storms mixed nutrients to the surface (Fig. 7B). Analyses by more sensitive methods indicate that $\mathrm{NO}_{\mathrm{x}}{ }^{-}$and $\mathrm{NH}_{4}{ }^{+}$levels in oligotrophic North Atlantic waters are only $\leq 0.003$ to $0.015 \mu \mathrm{M}$ (Brzezinski 1988, Harrison et al. 1996), sufficiently low to limit phytoplankton growth rates (Sunda \& Hardison 2007). Nutrient addition experiments confirm that phytoplankton growth in oligotrophic Sargasso waters is limited by available nitrogen (Moore et al. 2008).

Nutrient limitation may also increase DMSP:chl a and DLPA:chl a ratios in individual algal species. Nlimitation increased intracellular DMSP concentration by $88 \%$ in Emiliana huxleyi and by 30 -fold in the diatom Thalassiosira pseudonana (Keller et al. 1999) and increased the DMSP:chl a ratio by 5- to 9-fold in the diatom Skeletonema costatum (Sunda et al. 2007). It also increased the DMS to cell volume ratio by 20 -fold in E. huxleyi (CCMP 374) due to a large increase in DMSP lyase activity (Sunda et al. 2007). These findings suggest that at least some of the high DMSP, DLPA, and DMS per unit of chl $a$ in stratified surface ocean waters results from physiological responses of individual algal cells to nutrient limitation. Both factors physiological responses of individual cells and shifts in community composition - are likely important.

The importance of nutrient limitation is also supported by nutrient addition experiments. In an on-deck experiment with surface water from the Sargasso, the addition of $1 \mu \mathrm{M}$ ammonium and $0.062 \mu \mathrm{M}$ phosphate caused chl a concentrations to increase by 13-fold in $2 \mathrm{~d}$, compared to only a $13 \%$ increase in a no-addition control, indicating that the algal community was nutrient-limited (Harada et al. 2004). The addition of the nutrients caused ratios of DMSP, DLPA, and DMS to chl a to decrease by 6-, 7-, and 15-fold, respectively, after $2 \mathrm{~d}$ relative to control values.

In a similar experiment we conducted with Gallants Channel water, the addition of nutrients was also associated with much lower ratios of DMSP:chl $a$ and DMS:chl a than observed in a no-addition control (Figs. $8 \& 9$ ). Following the addition of $32 \mu \mathrm{M}$ nitrate and $2 \mu \mathrm{M}$ phosphate, chl $a$ increased by 2.7 -fold after $1 \mathrm{~d}$, and then decreased to twice the original value after $2 \mathrm{~d}$ (Fig. 8A). However, in the no-addition control, chl a decreased by 3 -fold after $1 \mathrm{~d}$ and by 5 -fold after $2 \mathrm{~d}$. This decrease was likely caused by nutrient limita-
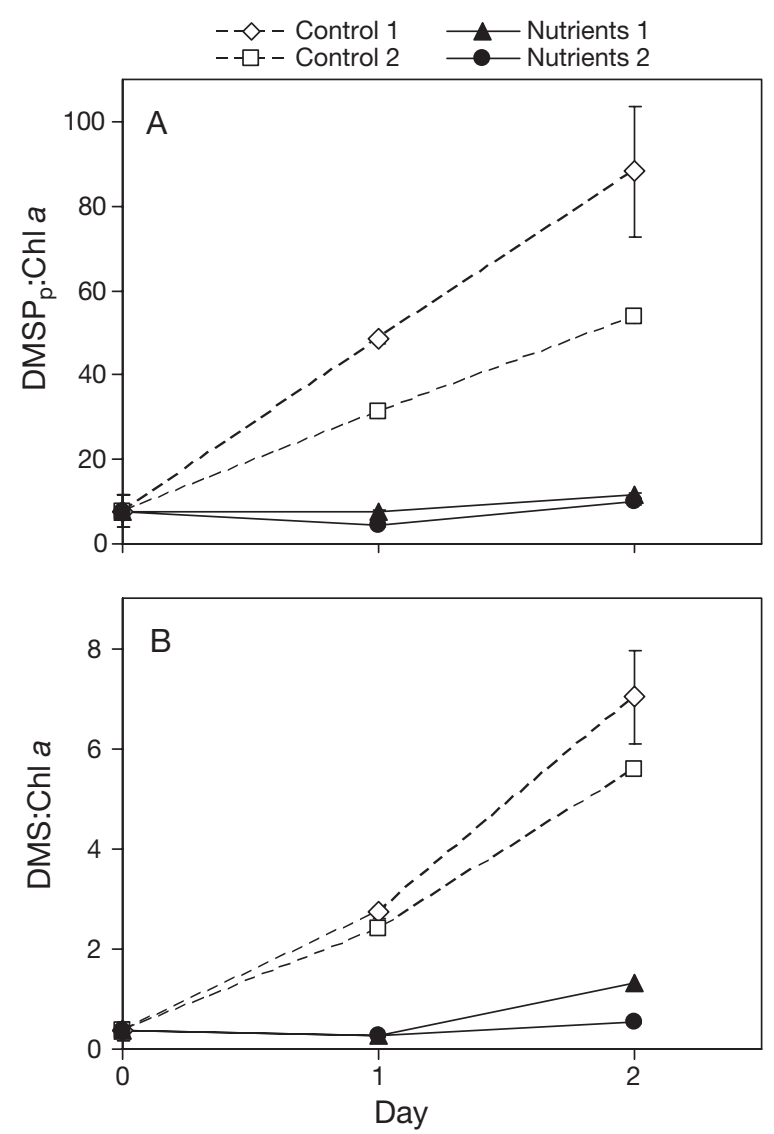

Fig. 9. Ratios of (A) DMSP $:$ chl $a$ and (B) DMS:chl $a$ for the nutrient addition experiment with Beaufort Dock water in July 2004. Each treatment had 2 replicate bottles. Data plotted as mean \pm range for duplicate measurements

tion, resulting from the loss of external sources of recycled nutrients from sediment regeneration and excretion by benthic animals, fish, and large zooplankton. Such recycled nutrient sources are important in this shallow estuary (Litaker et al. 1987), but would have been excluded once the sample water was collected. The addition of nutrients prevented this limitation from occurring until the second day of the experiment. The increase in chl $a$ in the nutrient-amended bottles after $1 \mathrm{~d}$ may have resulted largely from decreased grazing by excluded benthic grazers and large zooplankton rather than from an intrinsic increase in algal growth rate.

The 5-fold decrease in chl a in the no-addition control was accompanied by a 1.7 -fold increase in $\mathrm{DMSP}_{\mathrm{p}}$ and a 3.4-fold increase in DMS (Fig. 8B,C), which together caused an average 9-fold increase in the $\mathrm{DMSP}_{\mathrm{p}}$ :chl a ratio and an 18-fold increase in DMS:chl (Fig. 9). By contrast, in the nutrient addition bottles, average $\mathrm{DMSP}_{\mathrm{p}}$ :chl $a$ and DMS:chl a ratios decreased on Day 1 by 24 and $27 \%$, respectively, and then increased on Day 2 (by 1.8- and 3.5-fold, respectively) 
after nutrients became depleted (Fig. 9). Thus, in both the Sargasso and Gallants Channel experiments, nutrient addition was associated with substantially lower ratios of $\mathrm{DMSP}_{\mathrm{p}}$ and DMS to chl $a$. These effects were likely caused both by physiological shifts in individual algal species and by shifts in algal community composition.

\section{Solar UV radiation}

In addition to nutrient effects, the high DMS and $\mathrm{DMSP}_{\mathrm{p}}$ to chl a ratios in stratified surface ocean waters during the summer may also be linked to high exposure to solar UV radiation (Sunda et al. 2002, Toole \& Siegel 2004, Vallina \& Simó 2007). During summer, longer days and increased solar heating thermally stratify the water column, which results in shallow mixed layers and decreased nutrient mixing from deeper waters. The resulting decrease in nutrients invariably is accompanied by large increases in exposure of surface plankton to solar UV radiation owing to higher incident UV levels and decreased depth of the surface mixed layer (Simó \& Pedros-Alio 1999). Thus during the summer, the surface plankton will be simultaneously stressed by both nutrient limitation and high solar UV. Both factors are oxidative stressors that act synergistically (Litchman et al. 2002), and thus the surface plankton in thermally stratified oceanic waters experience very high overall levels of oxidative stress. In the winter there is a deepening of the mixed layer which brings nutrients to the surface and decreases UV exposure of surface plankton, leading to a substantial lessening of oxidative stress (Sunda et al. 2007). These effects are accompanied by large decreases in DMS and DMSP to chl a ratios (Figs. $4 \mathrm{C} \& 5 \mathrm{~B}$ ). Similar patterns are observed in certain oligotrophic shelf waters where there is sufficient depth to allow thermal stratification during summer and nutrient inputs from rivers is low (Vila-Costa et al. 2008).

In Gallants Channel and other shallow, tidally mixed coastal regions, waters remain well mixed to the bottom throughout the year, which ensures a steady input of recycled nutrients from bottom sediments. In Gallants Channel, high nutrients occur year-round (Fig. 7A) as do low DMS:chl a ratios. In addition, the phytoplankton in these waters are likely to experience low solar UV exposure because of high levels of solar UV attenuation from colored dissolved organic matter, plankton biomass, detritus, and suspended sediments (Sunda \& Huntsman 1994, Jerlov 1968). Thus, in these waters there should be much lower overall levels of oxidative stress.

Although solar UV exposure may be low year-round in Gallants Channel and the adjacent Newport River estuary, overall solar stress may be higher in winter than in summer owing to variable light conditions linked to a high frequency of low pressure frontal systems. Although rare in summer, these storm systems occur on average every 3 to $4 \mathrm{~d}$ in winter and lead to alternating periods of clouds, rain, and wind (and associated growth limiting light conditions) and calm sunny weather (Litaker et al. 2002). The resulting variable light can be oxidatively stressful (Niyogi 1999), and may help explain the higher occurrence of dinoflagellates during the winter and the co-occurring higher winter ratios of DMS and DMSP to chl $a$. Because of their diel patterns of vertical migration, these organisms are well adapted to varying light conditions and associated oxidative stress, as seen in their very high cellular levels of the photoprotective pigment diadinoxanthin (as discussed above) and DMSP (Sunda et al. 2005).

\section{Potential mechanisms for coastal-oceanic differences}

From the above discussion we see a general coherence between oxidative stress levels and DMS, DMSP $_{\mathrm{p}}$ and DLPA to chl a ratios, with the highest levels of each in stratified oligotrophic ocean waters in late spring through summer, and the lowest values in shallow, productive coastal systems during summer and early fall. These patterns fit well with the recently proposed antioxidant function of DMSP and its breakdown products (DMS, acrylate, and dimethylsulfoxide), based on the ability of these molecules to scavenge highly toxic hydroxyl radicals $(\cdot \mathrm{OH})$ produced metabolically under oxidative stress (Sunda et al. 2002). DMS and acrylic acid are, respectively, 60 and 20 times more reactive toward $\cdot \mathrm{OH}$ radicals than DMSP itself, and thus cells can greatly increase their protection from oxidative stress through the enzymatic lysis of DMSP into these products (Sunda et al. 2002). Such an increase in this protective mechanism could explain the very high values of $\mathrm{DMSP}_{\mathrm{p}}$, DLPA, and DMS relative to chl $a$ in oligotrophic ocean waters during the summer, both through acclimative up-regulation of cellular DMSP and DMSP lyase enzymes in individual species and through selection of algal species or strains with high DMSP and DLPA (Sunda et al. 2007, Vila-Costa et al. 2008). In addition, DMSP and DMS have been proposed to function as an energy overflow mechanism during unbalanced growth caused by nutrient limitation or variable light, a mechanism that would also help protect cells from oxidative stress (Stefels 2000).

DMSP and DMSP lyases have other metabolic functions which may also contribute to observed coastal- 
oceanic patterns. DMSP serves as an osmolyte in marine algae, and the higher DMSP:chl ratios in nutrient-depleted oceanic waters may result in part from cellular replacement of $\mathrm{N}$-containing osmolytes (e.g. proline) by DMSP (Turner et al. 1988). The proposed anti-grazing function of DMSP and DMSP lyase enzymes (Wolfe et al. 1997) may also be a factor. Species adapted to low-nutrient environments typically have robust grazing defense mechanisms (Sommer 1989), and if DMSP and DMSP lyases indeed function in grazing defense, then the coastal-oceanic patterns in ratios of DMSP, DLPA, and DMS to chl a would fit well with this mechanism.

None of the above proposed mechanisms for explaining the coastal-oceanic patterns in DMSP, DLPA, and DMS per unit of algal chl is mutually exclusive, and several (or all) may contribute to the high DMS to biomass ratios observed in nutrient-poor surface ocean waters relative to those in nutrient-rich, high-chl coastal waters. By enhancing DMS production per unit of algal chl in these low-biomass oceanic regions far removed from terrestrial nutrient sources, they may help to ensure a sufficient supply of DMS to the remote marine atmosphere to seed clouds and thereby drive the marine hydrological cycle and, through enhanced cloud reflectance (Charlson et al. 1987), help cool the earth's surface. A clearer knowledge of these biological-climate feedback interactions may become more important as global warming increases the thermal stratification of surface ocean waters and as anthropogenic inputs of nutrients increase eutrophication of coastal waters.

Acknowledgements. We thank W. Litaker for helpful comments on the manuscript.

\section{LITERATURE CITED}

Bates TS, Charlson RJ, Gammon RH (1987) Evidence for the climatic role of marine biogenic sulfur. Nature 329: 319-321

Brzezinski MA (1988) Vertical distribution of ammonium in stratified oligotrophic waters. Limnol Oceanogr 33: 1176-1182

Cantoni GL, Anderson DG (1956) Enzymatic cleavage of dimethylpropiothetin by Polysiphonia lanosa. J Biol Chem 22:171-177

> Charlson RJ, Lovelock JE, Andreae MO, Warren SG (1987) Oceanic phytoplankton, atmospheric sulfur, cloud albedo and climate. Nature 326:655-661

Dacey JWH, Howse FA, Michaels AF, Wakeham SG (1998) Temporal variability of dimethylsulfide and dimethylsulfoniopropionate in the Sargasso Sea. Deep-Sea Res 45: 2085-2104

Goericke R (1998) Response of phytoplankton community structure and taxon-specific growth rates to seasonally varying physical forcing in the Sargasso Sea off Bermuda. Limnol Oceanogr 43:921-935
Goldman JC, Mc Carthy JJ, Peavey DG (1979) Growth rate influence on the chemical composition of phytoplankton in oceanic waters. Nature 279:210-215

Harada H, Rouse M, Sunda W, Kiene RP (2004) Latitudinal and vertical distributions of particle-associated DMSP lyase activity in the western North Atlantic Ocean. Can J Fish Aquat Sci 61:700-711

Harrison WG, Harris LR, Irwin BD (1996) The kinetics of nitrogen utilization in the oceanic mixed layer: nitrate and ammonium interactions at nanomolar concentrations. Limnol Oceanogr 41:16-32

Iverson RL, Nearhoof FL, Andreae MO (1989) Production of dimethylsulfonium propionate and dimethylsulfide by phytoplankton in estuarine and coastal waters. Limnol Oceanogr 34:53-67

$>$ Jean N, Boge G, Jamet JL, Jamet D (2006) Comparison of $\beta$ dimethylsulfoniopropionate (DMSP) levels in two Mediterranean ecosystems with different trophic levels. Mar Chem 101:190-202

Jeffrey SW, Vesk M (1997) Introduction to marine phytoplankton and their pigment signatures. In: Jeffrey SW, Mantoura RFC, Wright SW (eds) Phytoplankton pigments in oceanography: guidelines to modern methods. UNESCO, Paris, p 37-84

Jerlov NG (1968) Optical oceanography. Elsevier, Amsterdam Keller MD, Bellows WK, Guillard RRL (1989a) Dimethyl sulfide production in marine phytoplankton. In: Saltzman ES, Cooper WJ (eds) Biogenic sulfur in the environment. American Chemical Society, Washington, DC, p 167-182

Keller MD, Bellows WK, Guillard RRL (1989b) Dimethylsulfide production and marine phytoplankton: an additional impact of unusual blooms. In: Cosper EM, Bricelj VM, Carpenter EJ (eds) Novel phytoplankton blooms. Springer-Verlag, Berlin, p 101-111

Keller MD, Kiene RP, Matrai PA, Bellows WK (1999) Production of glycine betaine and dimethylsulfoniopropionate in marine phytoplankton. II. N-limited chemostat cultures. Mar Biol 135:249-257

Kiene RP, Gerard G (1994) Determination of trace levels of dimethylsulfoxide (DMSO) in seawater and rainwater. Mar Chem 47:1-12

Kiene RP, Linn LJ (2000) Distribution and turnover of dissolved DMSP and its relationship with bacterial production and dimethylsulfide in the Gulf of Mexico. Limnol Oceanogr 45:849-861

Kiene RP, Slezak D (2006) Low dissolved DMSP concentrations in seawater revealed by small-volume gravity filtration and dialysis sampling. Limnol Oceanogr Methods 4: 80-95

Kilham P, Kilham SS (1980) The evolutionary ecology of phytoplankton. In: Morris I (ed) The physiological ecology of phytoplankton. Blackwell, London, p 571-597

Kwint RLJ, Kramer KJM (1996) Annual cycle of the production and fate of DMS and DMSP in a marine coastal system. Mar Ecol Prog Ser 134:217-224

> Litaker W, Duke CS, Kenney BE, Ramus J (1987) Short-term environmental variability and phytoplankton abundance in a shallow tidal estuary. Mar Biol 96:115-121

> Litaker RW, Tester PA, Duke CS, Kenney BE, Pinckney JL, Ramus J (2002) Seasonal niche strategy of the bloomforming dinoflagellate Heterocapsa triquetra. Mar Ecol Prog Ser 232:45-62

Litchman E, Neale PJ, Banaszak AT (2002) Increased sensitivity to ultraviolet radiation in nitrogen-limited dinoflagellates: photoprotection and repair. Limnol Oceanogr 47: 86-94

Lyons DA, van Alstyne KL, Scheibling RE (2007) Anti-graz- 
ing activity and seasonal variation of dimethylsulfoniopropionate-associated compounds in the invasive alga Codium fragile ssp. tomentosoides. Mar Biol 153: 179-188

Moore CM, Mills MM, Langois R, Milne A, Achterberg EP, La Roche J, Geider RJ (2008) Relative influence of nitrogen and phosphorus availability on phytoplankton physiology and productivity in the oligotrophic sub-tropical North Atlantic Ocean. Limnol Oceanogr 53:291-305

Moret I, Gambaro A, Piazza R, Barbante C, Andreoli C, Corami F, Scarponi G (2000) The seasonal variations of dimethyl sulphide and carbon disulphide in surface waters of the Venice lagoon. Mar Chem 71:283-295

Niyogi KK (1999) Photoprotection revisited: genetic and molecular approaches. Annu Rev Plant Physiol Plant Mol Biol 50:333-359

Ornolfsdottir DJ, Pinckney JL, Tester PA (2003) Quantification of the relative abundance of the toxic dinoflagellate, Karenia brevis (Dinophyta), using unique photopigments. J Phycol 39:449-457

Parsons TR, Maita Y, Lalli CM (1984) A manual for chemical and biological methods for seawater analysis. Pergamon Press, Oxford

Porra RJ, Pfündel EE, Engel N (1997) Metabolism and function of photosynthetic pigments. In: Jeffrey SW, Mantoura RFC, Wright SW (eds) Phytoplankton pigments in oceanography: guidelines to modern methods. UNESCO, Paris, p 85-126

Simó R, Pedros-Alio C (1999) Role of vertical mixing in controlling the oceanic production of dimethylsulfide. Nature 402:396-399

Sommer U (1989) The role of competition for resources in phytoplankton succession. In: Sommer U (ed) Plankton ecology. Springer-Verlag, Berlin, p 57-106

Stefels J (2000) Physiological aspects of the production and conversion of DMSP in marine algae and higher plants. J Sea Res 43:183-197

Stefels J, Dijkhuizen L, Gieskes WWC (1995) DMSP-lyase activity in a spring phytoplankton bloom off the Dutch coast, related to Phaeocystis sp. abundance. Mar Ecol Prog Ser 123:235-243

Steinke M, Wolfe GV, Kirst GO (1998) Partial characterisation of dimethylsulfoniopropionate (DMSP) lyase isozymes in six strains of Emiliania huxleyi. Mar Ecol Prog Ser 175:215-225

Sunda WG, Hardison DR (2007) Ammonium uptake and

Editorial responsibility: Douglas Capone,

Los Angeles, California, USA growth limitation in marine phytoplankton. Limnol Oceanogr 52:2496-2506

Sunda WG, Huntsman SA (1994) Photoreduction of manganese oxides in seawater. Mar Chem 46:133-152

Sunda W, Kieber DJ, Kiene RP, Huntsman S (2002) An antioxidant function for DMSP and DMS in marine algae. Nature 418:317-320

Sunda WG, Litaker RW, Hardison DR, Tester PA (2005) Dimethylsulfoniopropionate (DMSP) and its relation to algal pigments in diverse waters of the Belize coastal lagoon and barrier reef system. Mar Ecol Prog Ser 287:11-22

Sunda WG, Hardison R, Kiene RP, Bucciarelli E, Harada H (2007) The effect of nitrogen limitation on cellular DMSP and DMS release in marine phytoplankton: climate feedback implications. Aquat Sci 69:341-351

> Tester PA, Geesey ME, Guo C, Paerl HW, Millie DF (1995) Evaluating phytoplankton dynamics in the Newport River estuary (North Carolina, USA) by HPLC-derived pigment profiles. Mar Ecol Prog Ser 124:237-245

> Todd JD, Rogers R, Li YG, Wexler M and others (2007) Structural regulatory genes required to make the gas dimethyl sulfide in bacteria. Science 315:666-669

Toole DA, Siegel DA (2004) Light-driven cycling of dimethylsulfide (DMS) in the Sargasso Sea: closing the loop. Geophys Res Lett 31:L09308

Turner SM, Malin G, Liss P, Harbour DS, Holligan PM (1988) The seasonal variation of dimethylsulfide and dimethylsulfoniopropionate concentrations in nearshore waters. Limnol Oceanogr 33:364-375

Vallina SM, Simó R (2007) Strong relationship between DMS and the solar radiation dose over the global surface ocean. Science 315:506-508

Vila-Costa M, Kiene RP, Simó R (2008) Seasonal variability of the dynamics of dimethylated sulfur compounds in a coastal northwest Mediterranean site. Limnol Oceanogr 53:198-211

Wolfe GV, Steinke M (1996) Grazing-activated production of dimethylsulfide (DMS) by two clones of Emiliania huxleyi. Limnol Oceanogr 41:1151-1160

Wolfe GV, Steinke M, Kirst GO (1997) Grazing-activated chemical defence in a unicellular marine alga. Nature 387: 894-897

Yoon HS, Hackett JD, Bhattacharya D (2002) A single origin of the peridinin- and fucoxanthin-containing plastids in dinoflagellates through tertiary endosymbiosis. Proc Natl Acad Sci USA 99:11724-11729

Submitted: February 8, 2008; Accepted: October 10, 2008

Proofs received from author(s): December 1, 2008 